\title{
CORRIGENDUM
}

\section{Findings in an independent sample support an association between bipolar affective disorder and the G72/G30 locus on chromosome 13q33}

Y-S Chen, N Akula, SD Detera-Wadleigh, TG Schulze, J Thomas, JB Potash, JR DePaulo, MG McInnis, NJ Cox and FJ McMahon

Molecular Psychiatry (2004) 9, 811. doi:10.1038/sj.mp.4001539

Correction to: Molecular Psychiatry (2004) 9, 87-92. doi: 10.1038/sj.mp. 4001453

In Table 1, page 90, the first two cells contain incorrect characters. The SNP name should read rs2027446 and the chromosome position should read 100496965. 